\title{
Librarians or Revolutionaries? The Debate about Cuba's Independent Library Movement
}

\author{
by Paula Farrar
}

Bio Note: Paula has worked in Vancouver's largest children's bookstore and also in the University of British Columbia Science Library. She will complete her MLIS from the University of British Columbia in 2004. This essay was adapted from a paper written for a class on Intellectual Freedom. Email <pfarrar@interchange.ubc.ca>

"In Cuba there are no prohibited books, only those we do not have the money to buy."

- Fidel Castro 1998

In 1998 this statement sparked the creation of the Independent Library Movement in Cuba, a movement that quickly grew from one library to more than one hundred libraries. In spite of the fact that there already existed a well developed library system in Cuba, these libraries claimed as their mandate that they would supply the Cuban people with material not available in the national system. In essence they were putting Castro's conviction, that there are no censored books in Cuba, to the test. Over the years since their opening, the independent libraries have reported various instances of harassment from the Cuban government, and most recently, in the spring of 2003, fourteen independent "librarians" were sentenced to long prison terms. I put librarians in quotation marks as the individuals running the independent libraries are not certified librarians. According to John Pateman of the Cuban Libraries Solidarity Group, "[a]ll of the main people involved in the project belong to 'independent press agencies' and 'oppositional political parties'. None of them are qualified librarians or members of the Cuban Library Association (ASCUBI)" (2000, p.1). The sentencing of the "librarians" was a result of "...a major government crackdown on dissidents in the country. Cuba says the dissidents were arrested for accepting U.S. government money, a charge U.S. officials deny" (McClelland, 2003, p.3). This statement highlights the key element of the controversy surrounding the Independent Library Movement in Cuba: are they revolutionaries trying to overthrow the Cuban government or are they persecuted librarians taking a stand on intellectual freedom? This essay strives to present the major issues involved in this controversy by examining the current political and economic situation in Cuba, the state-run "official" libraries, the independent libraries, the groups that support either side of the debate, and the response from the Canadian Library Association (CLA) and American Library Association (ALA), as well as the International Federation of Library Associations and Institutions (IFLA). 


\section{The Economic and Political Situation in Cuba}

Before delving into the details of this topic, it is important first to look at the political and economic context in which this debate lies. Supporters of the Independent Libraries state they are concerned exclusively with defending intellectual freedom, and believe that intellectual freedom does not exist in Cuba. Their argument fails to place the issue of intellectual freedom within a larger context. However, some of the main arguments used in defense of Cuba on the issue of intellectual freedom, rest on the poor economic situation of the country and the fact that Cuba has been suffering under a 40 year trade embargo. They propose it is economics, not censorship that has kept Cuban Libraries from expanding their collections.

In 1959, Fidel Castro led a socialist revolution that overthrew the U.S. backed Batista dictatorship. At that time, "...the vast majority of people were impoverished and underemployed” (Cuban Libraries Solidarity Group, 2003). Since the Socialist revolution began there have been many positive improvements in Cuban society. Cuba has made giant strides in eliminating illiteracy and has created a free and universal education system and health care system (Acosta, 2003). According to the Cuban Libraries Solidarity Group, today Cuba has:

- a widely respected, free education service which has raised Cuban educational standards to the highest in Latin American (UNESCO, 1998).

- $\quad$ education for all. The percentage of children at school jumped from $50 \%$ to $80 \%$ between 1959 and 1962 . Today all children attend school and are guaranteed a minimum ninth grade education.

- $\quad$ preschool education for the children of working mothers. $90 \%$ of pre school children attend nursery school and the percentage continues to rise.

- comprehensive higher education. Today every province has its own university, while before the revolution there were only three.

- $\quad$ special needs education for all who need it, either in special or mainstream schools. This is unique in the Third World. The staffing ratio is much higher than in Britain.

- eliminated illiteracy (endorsed by UNESCO statistics). This is a national priority. Illiteracy plummeted during the Great Literacy Campaign of 1960/1961 and has continued to fall, while in the United States it stands at $12 \%$.

- a well developed infrastructure of public, academic, and special libraries.

- $\quad$ over 300 public libraries, which possess over 7 million titles, nearly 6 million of them books. Public libraries are used by 5.9 million people, 
borrowing 8 million books per year.

- nine publishing houses which produce over 2,000 per year, with a total print run of more than 45 million copies, equivalent to more than 20 titles per 100,000 inhabitants.

(Cuban Libraries Solidarity Group, 2003).

Perhaps what is the most amazing thing about Cuba is that it has managed to do all of this while enduring a crippling trade embargo imposed by the United States since 1961.

The U.S. led trade embargo plays a major role in the discussion of intellectual freedom in Cuba. Many arguments have boiled down to the fact that when a country finds itself in a state of siege, a state of war, many freedoms are restricted or even lost. This is not only the case in Cuba, it can be seen the world over. According to Amnesty International, "...the US embargo has helped to undermine the enjoyment of key civil and political rights in Cuba by fuelling a climate in which such fundamental rights as freedom of association, expression and assembly are routinely denied" (2003). The argument is strengthened by the fact that, "...the Cuban authorities have systematically defended their repressive legal system on the grounds that states under aggression have the right to restrict freedoms in the interests of national security" (Amnesty International, 2003). Since the collapse of the Soviet Union, Cuba's primary trading partner, Cuba has endured even greater hardships under the embargo. And, "[e] very year since 1992, the UN General Assembly has voted to condemn the U.S. policy toward Cuba. In November 2001, that vote was 167-3, with only Israel and the Marshall Islands siding with the United States" (Mote, 2000). In her report on her findings after a trip to Cuba, Susanne Seidelin of IFLA stated,

In our discussions with Cuban representatives, the direct and indirect affects of the US embargo were repeatedly identified as the most important issue concerning access to information in Cuban libraries. Considering the standard of the libraries we visited, which probably are among the best resourced in the country, we have no doubt that the embargo seriously damages the capacity of the Cuban people to access information despite the formal exclusion of information materials from the embargo. (Seidelin, 2001).

Interestingly enough, all groups concerned with the issue of intellectual freedom in Cuba condemn the blockade, except for the Independent Libraries and their supporters.

Economically, Cuba has suffered under the hostile trade embargo imposed by the U.S., but Cuba has also suffered politically through the actions of the U.S. "Cuba has been high on the U.S. political agenda since the U.S. backed Batista regime was removed from power in Castro's revolution of 1959" (Hamilton, 2002, p. 51). The United States spends millions of dollars every year to help overthrow the Cuban government. With the Torricelli Act in 1992, the U.S. tightened the trade 
embargo with greater restrictions on food and medicine, as well as passing a new piece of legislation that provided funds to anti-government organizations in Cuba. "In 1996 the U.S. went even further when it passed Cuban Liberty and Democratic Solidarity (LIBERTAD) Act, also known as the Helms-Burton Act, which increased the aid to anti-government groups" (Hamilton, 2002, p.32). According to McClelland, the U.S., “...has given more than \$20 million since 1997 to non-governmental groups in the United States to support Cuba's opposition movement and promote democracy, human rights and free enterprise in Cuba. The U.S. government broadcasts American propaganda into Cuba through radio and television reports, which cost about $\$ 25$ million annually" (2003, p. 5). Facing this kind of aggression, both economically and politically from its powerful neighbour to the north, Cuba finds itself in a semi-state of war. Bringing this back to the issue of intellectual freedom, Ann Sparanese makes the poignant observation:

We have no idea what Cuba might be like, were the U.S. aggression and blockade to end tomorrow. The flowering of Cuban culture and arts, intellectual and sports achievements, healthcare excellence and the educational level of the common people are incredible and acknowledged throughout the world. And this, under conditions of less than perfect political freedom - who knows what Cuba might accomplish without the constant military and economic threats and crises, covert and overt aggressions provoked and carried out by the U.S. government. (Sparanese, 1999, p.14).

The most commonly expressed opinion amongst the debaters on the issue of intellectual freedom in Cuba is that Cuba can not be judged until the U.S. ends its overt and covert aggression against this country. Once again the Independent Libraries and their supporters are the only ones who do not call for an end to U.S. aggression against Cuba.

\section{The "Official”" Libraries of Cuba}

Before discussing the Independent Library Movement in Cuba, it is important first to look at the "official" state-run libraries, as the Independent Libraries claim they are providing a service not offered by these institutions. Cuba has an extensive library system encompassing public, school, academic and special libraries, as well as two professional library associations: the Association of Cuban Librarians (ASCUBI) and the Cuban Society of Information Sciences (SOCICT). "Cuba's well-organized libraries provide services to thousands of people every day. The island's 391 public libraries - one for every 26,000 people provide materials to many different types of users and are complemented by school, university and special libraries" (Hamilton, 2001, p.5). After visiting various "official" libraries, Larry Oberg made the statement:

Cuban librarians carry out many of the same activities as their North American counterparts. They strive to build broad in-depth collections that reflect their cultural and national identity and provide access to information and reference services to students, researchers, other professionals and the 
Cuban population as a whole. They organize and preserve materials in diverse formats, create tools that aid patrons in the use of their collections and, increasingly, employ electronic technologies to organize, format and deliver information. As professionals, they participate in degree programs, conferences, instructional workshops and professional associations. They lobby for increased funding to develop coordinated library services, a national online catalog, and strong distance education programs. (Oberg, 2001, p.5).

According to Neugebauer, "Librarians look for and deposit in their collection materials with many different viewpoints, including materials that are critical of the revolution, materials written by Cubans living abroad, and materials on human rights, such as the UN Universal Declaration of Human Rights" (2001, p. 7). Another area that shows the commitment of the "Official" Librarians is their outreach programs. "Cuban librarians take their outreach obligations seriously and have invested heavily in bookmobiles and branch libraries in isolated rural locations. They are particularly committed to making libraries services available to rural Cuban children" (Oberg, 2000, p. 7).

Both the International Federation of Library Associations (IFLA) and the American Library Association (ALA) have sent members to Cuba to investigate the issue of intellectual freedom and censorship. From these various visits, many reports have been written that confirm the fact that the "official" Cuban libraries are doing the very best they can with very limited resources. In the IFLA report Seidelin makes the comment that, "...the titles that are only available in one copy are always kept in closed shelves and must be read at the library, a practice well known in libraries all over the world. Furthermore, when one evaluates the practice of Cuban libraries, both the poor condition of most books and the shortage of funding should be taken into account" (2001). In her conclusion Seidelin states:

With the limited resources at their disposal, the librarians are doing a very professional job. The services for the blind and visually impaired deserve special mention - a national library with a whole room reserved for services for the handicapped is seldom seen. In addition, the variety of activities for children and adults and the role art plays in everyday life in the libraries are impressive. (Seidelin, 2001).

And as Hamilton states, "....the economic circumstances the country finds itself in as a result of the withdrawal of Soviet aid and the US embargo mean library budgets are small. This leads to under-developed collections, services and preservation programs" (2001, p.10). Finally, Eliades Acosta, the National Library Director, makes the statement, "[w] are not brutal censors. Selection is not censorship. We have the right to choose the titles ourselves on background of quality and economy. It is not the government that selects the books but the librarians. We have a selection policy, not censorship" (Seidelin, 2001).

\section{The Independent Libraries}

The plight of the independent libraries came to the attention of the 
international community through the efforts of a United States based organization, The Friends of Cuban Libraries. This organization claims to be concerned exclusively with defending intellectual freedom in Cuba, and has been lobbying such organizations as the American Library Association, the Canadian Library Association, The International Federation of Library Associations, and Amnesty International to take action on behalf of the independent libraries. The first independent library in Cuba opened in 1998 in the apartment of Berta Mexiodor, an economist, and her husband Ramon Colas, a psychologist. Since then, the number of independent libraries has grown to over one hundred spread throughout the country. Robert Kent makes the assertion that the independent libraries were formed, "...to challenge the Cuban government's monopoly on information, with the specific goal of providing uncensored books and materials reflecting perspectives on all sides of issues to the Cuban people" (American Library Association, 2001a, p. 89). According to John Pateman the aims of the Independent Library movement are to:

1. Offer scientific, technical, cultural and general information

2. Offer libraries in all municipalities and provinces

3. Create inter library cooperation at home and abroad

4. Create an open forum for discussion among readers

5. Stimulate reading among youth and children

6. Promote literary research and development

(Pateman, 2000, p. 41).

He further makes the assertion that, "all of these aims are being met by the Cuban library system" (Pateman, 2000, p. 42). If in fact Pateman is correct, and the independent libraries are not providing additional services, it follows that their stated reason for existence might be called into question.

The three major questions in the debate on the issue of the independent libraries are: whether they are run by "librarians" and constitute real "libraries"; whether they are really "independent"; and whether the directors of these libraries are being persecuted for providing uncensored material or for being political dissidents. In answering the first question it seems quite apparent that the individuals running these libraries are not "librarians" in the strictest sense of the word. According to Seidelin, "it is true that the independent libraries are not run by trained librarians, and that the buildings do not display their function, and that acquisition and other professional activities may not be managed according to professional standards"(2001). In fact, it seems the only common thread connecting the various Independent Librarians is their opposition to the Castro government. "To describe the directors of the independent libraries as librarians therefore is misleading, and enables champions of the project abroad to raise sympathy for dissidents by labeling them as librarians - dedicated professionals who are doing their job to bring information to the disenfranchised people of Cuba" 
(Hamilton, 2001, p. 105). The Director of the National Library, Eliades Acosta states, "[t]hey are not librarians or promoters of culture. Many do not have jobs. They want to defect to the United States, but they do not have the necessary background as political dissidents that the U.S. Interests Section requires. Becoming a persecuted librarian is one way for them to get the required documents" (American Library Association, 2001b, p.32). From his visit to two independent libraries, Larry Oberg concludes:

Neither of the two 'independent' libraries were marked or signed in any way as libraries. One had no collection whatsoever and the other had a modest collection of materials of a size that one might expect to find in any Cuban home. The one collection that I saw was not catalogued or even organized by subject. There was no circulation apparatus and this collection had no materials to support its primary collecting goals, children's literature. (Oberg, 2000, p.14).

All of these statements make clear that the individuals involved in the Independent Library Movement are not professional librarians and even provide evidence that one might not consider them even "libraries".

The next issue to look at is whether the independent libraries are actually "independent". According to Hamilton, "[m]ost contentious is the support received from the U.S. government which supplies aid in the form of books delivered to the independent libraries by its Interest Section in Havana" (2001, p. 27). Oberg confirms this in his report stating:

A number of the so-called independent librarians told us that they depend upon gifts of printed materials, fax machines, telephones, and video and audio recorders that, in many cases, are delivered directly to their homes by members of the U. S. Interest Section in Havana. Some admitted that they depend upon financial support, and owe allegiance to, their allies in the anti-Castro Cuban community in Miami and elsewhere abroad. (Oberg, 2001, p. 8).

Neugebauer goes even further commenting on her findings from her visit to Cuba in 2001:

We confirmed that the owners are not independent. We confirmed that the owners have political objectives and are using their "libraries" to distribute anti-government propaganda. We confirmed that the owners have ties to groups in Miami as well as to the U.S. Government - both of which have been involved in trying to overthrow the Cuban government. The owners of these "independent libraries" regularly receive materials directly from the U.S. Interests Section in Cuba. (Neugebauer, 2001, p. 15).

With it being clearly stated by the independent libraries that they are receiving material from the United States it is easy to ask the question whether they are really "independent". Once again the political context of this issue clouds the debate. 
The final question is centered on the harassment, persecution, and most recent jailing of independent librarians. According to the Friends of Cuban Libraries, a U.S. based organization, the librarians are being persecuted solely on the grounds that they are librarians offering uncensored materials. Hamilton counters this argument with a conversation he had with an independent librarian: "When asked if she was detained for her collection of books and her library activities, Garcia answered that she was taken in for her counter-revolutionary activities, not her library" (Hamilton, 2001, p. 97). Larry Oberg encountered the same response when he questioned various independent librarians on his trip in 2000. He states: "The independent librarians that I met are all self-possessed political dissidents, dedicated to the overthrow of the Cuban government. Several had been arrested by the Cuban authorities, but they emphasized that these arrests had nothing to do with their independent library activities" (Oberg, 2000, p.15). These statements, along with the Cuban government's assertion that the arrests and sentencing of the independent librarians are because of their counterrevolutionary activities and not their libraries, throw doubt on the argument that the independent librarians are being persecuted for offering censored materials.

\section{Supporters and Detractors of the Independent Libraries}

The only group presently taking a stand to support and promote the independent library movement is the Friends of Cuban Libraries. According to their website they were founded in June 1999 and, "....are an independent, nonpartisan, nonprofit organization dedicated to promoting intellectual freedom in Cuba, regardless of whatever government may be in office" (Friends of Cuban Libraries, 2003). The founders of this organization are Robert Kent, a New York City librarian, and Jorge Sanguinetty. Jorge Sanguinetty, "....was head of Cuba's Department of National Investment Planning before he left the country in 1967 . He is also a newspaper columnist and a commentator on Radio Marti, a U.S. government funded radio station which broadcasts anti-Cuban programs" (Pateman, 1999/2000, p. 2). Robert Kent has connections with Freedom House and the Center for a Free Cuba, and on numerous occasions has taken both books and pamphlets to Cuba for them. "Freedom House is an anti-Castro organization which has received $\$ 500,000$ (from USAID and the US Information Agency) in US government funding" (Pateman, 1999/2000, p. 4). According to Hamilton,

Both men's backgrounds and positions warrant further investigation, especially as FCL claims to be an independent and non-partisan organization. Their connections with institutions openly mentioned in FCL press releases, such as Freedom House, The Center for a Free Cuba, Radio Marti and the U.S. Agency for International Development must be questioned and, in turn, the significance of these organizations in the wider picture of the U.S.'s relationship with Cuba can be considered. (Hamilton, 2001, p. 46).

Perhaps the most interesting point made by the Friends of Cuban Libraries is in regard to the U.S. trade embargo. "We do not comment on the U.S. trade embargo because we focus exclusively on intellectual freedom issues" (Friends of 
Cuban Libraries, 2003). Larry Oberg responds to this statement by commenting, "The Friends of Cuban Libraries and their sympathizers wish to conduct a sterile and abstract discussion of Cuba and its libraries, a conversation devoid of context. In this manner, they can hold Cuba to an abstract standard that no other country in the world - certainly including our own [the U.S.] - is held to, or can claim to have reached" (Oberg, 2001, p. 11).

One month after the formation of the Friends of Cuban Libraries, the Cuban Libraries Solidarity Group (formerly the Cuban Libraries Support Group) was established. The CLSG was created by John Pateman an English librarian, "....in order to counteract the defamatory and counter-revolutionary campaign generated by the Independent Libraries Movement" (Pateman, 2002/2003, p. 8). As an organization, the CLSG states that their objectives are to support:

- Cuban libraries, librarians, library and information workers and the Cuban Library Association (ASCUBI).

- Cuba's free and comprehensive education system and high literacy levels

- The Cuban people's right to self-determination and to choose the social, political and economic systems which support their library service.

(CLSG, 2003).

The CLSG is quite clear on their position in regard to U.S. relations with Cuba. They state that they have campaigned for: "... respect for Cuba's right to sovereignty and independence; an end to interference in Cuba's internal affairs by foreign governments; an end to the US economic blockade of Cuba; the normalization by the US of all diplomatic, cultural, scientific and travel relations with Cuba" (CLSG, 2003). The CLSG does not support the Independent Library Movement: according to founder John Pateman, "[n]ot one of these so-called libraries is a library, and not one of the allegedly repressed librarians is, or ever was, a professional librarian, they are professional dissidents" (1999/2000, p. 5). The Cuban Libraries Solidarity Group also works in partnership with four other organizations: Information for Social Change; The Chartered Institute of Library and Information Professionals; Book Aid International; and the Cuba Solidarity Campaign.

\section{The Response from the CLA, ALA, \& IFLA}

The Independent Library Movement first came to the attention of the international community, including various library associations, through the efforts of Robert Kent and the Friends of Cuban Libraries. For the most part the initial response was genuine concern for these oppressed librarians and an immediate condemnation of Cuba on the grounds that it was suppressing intellectual freedom. However, after further investigations (IFLA and the ALA have both sent 
delegations to Cuba to investigate both the official and independent libraries in Cuba), it has been revealed that the topic is much more complicated than Robert Kent had suggested. At this point in time the CLA, ALA, and IFLA have not passed resolutions in support of the Independent libraries; however, on the issue of intellectual freedom in Cuba all three of the associations have passed resolutions calling for the end of the U.S. trade embargo. At its 2003 annual general meeting the CLA passed a resolution calling,

...on the International Federation of Library Associations and Institutions to convene an international Commission of eminent librarians to hold public hearings to further investigate the role of 'independent' libraries in Cuba and charges that they are funded through foreign agencies whose political program is regime change. (Canadian Library Association, 2003, p.191).

In the ALA, in addition to not taking a stance in support of the Independent Library Movement, many members have squared off with Robert Kent on the issue. Mark Rosenweig, Social Responsibilities Round Table (SRRT) member, “... has been present in the debate from the beginning and has consistently criticized [the Friends of Cuban Libraries] for not taking a stance on the US embargo and their reluctance to officially comment on political issues" (Hamilton, 2001, p. 72). Ann Sparanese, another SRRT member even participated in a debate with Robert Kent on the issue of intellectual freedom in Cuba, in which she makes the poignant remark, "...I think that we have intellectual freedom concerns right here in our country, in our own libraries, in our own profession. Why are we holding Cuba up to a standard that is not even observed by most countries in the world, even our own?" (American Library Association, 2001a, p.88).

Since the arrest of the independent librarians last spring, the ALA has been repeatedly chastised for not taking a stance in support of the independent library movement. As one journalist wrote, "[a]n association supposedly dedicated to freedom of information, inquiry and expression said nothing about Cuba's brutal crackdown against private home libraries and librarians" (Call to Conscience, 2004). Most recently at its midwinter meeting the ALA did make a statement in regard to Cuba; however it is unlikely to placate the supporters of the independent libraries. The ALA's press release on Cuba states,

ALA supports IFLA in urging the Cuban government to eliminate obstacles to access to information imposed by its policies, and IFLA's support for an investigative visit by a special rapporteur of the United Nations Commission on Human Rights with special attention given to freedom of access to information and freedom of expression, especially in the cases of those individuals recently imprisoned and that the reasons for and conditions of their detention be fully investigated.

Proclaiming the fundamental right of all human beings to access information without restriction, ALA joins with IFLA in urging the Cuban library community to monitor violations of freedom of access to information and freedom of expression and to take a leading role in actively promoting these basic rights for all Cubans. (American Library Association, 2004). 
Thus, as of early 2004, the ALA had not passed a resolution to support the independent library movement, only to support IFLA and further investigation. According to a January 26 ALA Press Release, the association "continued its call, with IFLA, for the elimination of the U.S. embargo that restricts access to information in Cuba and for lifting travel restrictions that limit professional exchanges. ALA joined IFA to express "deep concern" over the arrest and long prison terms of political dissidents in Cuba in spring 2003 and urged the Cuban Government to respect human rights defined in Article 19 of the Universal Declaration of Human Rights" (ALA and Cuba, 2004). Following this announcement, syndicated columnist Nat Hentoff, and winner of ALA's Immroth Award for Intellectual Freedom in 1983, strongly criticized ALA council for not passing a stronger resolution that was critical of Castro and would demand the release of the "independent" librarians. Hentoff has requested that his name be withdrawn from the list of Immroth award winners. (Hentoff, 2004). Although IFLA has not taken a stand to support the Independent Library movement, it has expressed growing concern in regard to the issue of intellectual freedom in Cuba. Most recently, IFLA issued a media release stating its concern regarding the Cuban government's latest attempt to restrict internet access, as well as its support of "... the Cuban library community in safeguarding and implementing the principles of the IFLA Internet Manifesto" (IFLA, 2004).

\section{Conclusion}

In examining the Independent Library Movement in Cuba, I find it impossible to come to a black and white, right or wrong conclusion. What does seem clear is that the directors of the Independent Library Movement have been harassed and persecuted by the Cuban government on the grounds that they are participating in anti-government activities and are receiving funds from a foreign power to do so. Whether these individuals are also being persecuted for their libraries has not been proven, and whether these individuals should be called librarians is still up for debate. As Edward Erazo asks, "If you have 100 books in your home and you make them available to friends, are you a librarian?" (Lee, 2003, p.B7). How this all relates to issue of intellectual freedom in Cuba has been debated passionately over the past few years. From the various groups that have organized over this issue, to the various library associations that have sent fact finding delegations to Cuba, to the statements made by Cubans themselves, the one truth that everyone seems to agree on, is that Cuba is suffering an information blockade. Whether this is an internal blockade imposed by censors in the Cuban government, or an external blockade imposed by the U.S. trade embargo is not altogether clear. What does seem to stand out is that in order to get to the bottom of this, the U.S. needs to heed the call of the international community and end the embargo. Until that time, "...librarians will have to decide whether intellectual freedom and access to information, among our most cherished principles, are ideals to be defended regardless of social and historical reality" (Campbell, 2003).

\section{References}

Acosta, Eliades. (2003). "Cuban Libraries: The Interview Waiting for CNN." Cuban 
Libraries Solidarity Group Press Release July 19. Accessed January 17, 2004 at http://libr.org/CLSG/ .

ALA and Cuba: Who's Afraid of Nat Hentoff? (2004) American Library Association Press Release January 26, 2004. Accessed February 2, 2004 at: www.lisnews.com.

American Library Association. (2001a). Intellectual freedom in Cuban libraries: Does it Exist? American Libraries 32(4): 87-91.

American Library Association. (2001b). Cuba's National Library. American libraries 32(2): 30-32.

American Library Association. (2004). International Relations Committee and Intellectual Freedom Committee's Report on Cuba. American Library Association Press Releases. Accessed January 17, 2004 at: http://www.ala.org/.

Amnesty International. (June 2003). Human Rights Crackdown in The Name of Security." Amnesty International. Accessed January 17, 2004 at:

http://web.amnesty.org/library/lndex/.

Call to conscience: Library group is shamefully silent on Cuba. The Friends of Cuban Libraries: Recent News. Union-Tribune Editorial. (9 January 2004). Accessed January 17, 2004 at: http://www.friendsofcubanlibraries.org/

Campbell, Brian. (2003). "Independent” Libraries in Cuba. Cuban Libraries Solidarity Group: Press Release July 4. Accessed January 17, 2004 at: http://libr.org/CLSG/.

Canadian Library Association. (2003). Minutes. Feliciter 49 (4): 191.

Cuban Libraries Solidarity Group. (2003). Cuban Libraries Solidarity Group Homepage. Accessed January 17, 2004 at: http://libr.org/CLSG/.

Friends of Cuban Libraries. (2001). FAQs. Friends of Cuban Libraries. Accessed January 17, 2004 at: http://www.friendsofcubanlibraries.org/index.htm.

Hamilton, Stuart. (2002). Librarians or Dissidents?: Critics and Supporters of the Independent Libraries in Cuba Project." Progressive Librarian 19-20. Accessed January 17, 2004 at: http://www.libr.org/PL/19-20 Hamilton.html.

Hentoff, Nat. (2004, January 29). The Abandoned Librarians. The Village Voice. Accessed February 23, 2004 at: http://www.villagevoice.com.

IFLA. (2004). Librarians' deep concern over Cuba's move to restrict Internet access. FAIFE Media Release January 16. Accessed January 17, 2004 at: http://www.ifla.org/.

Lee, Felicia R. (2003, June 28). A library in Cuba: What is it?. The New York Times, B7. 
McClelland, Colin. (2003). Cuban Librarian Accuses Washington of Funding Dissidents. Associated Press Worldstream June 21, 2003. Accessed January 17, 2004 at: http://www.veteranscava.org/.

Mote, Patty. (2000). FAQs. National Network on Cuba. Accessed January 17, 2004 at: http://www.cubasolidarity.com.

Neugebauer, Rhonda. (2001). Cuban Libraries: Challenges and Achievements. Information for Social Change 13. Accessed January 17, 2004 at: http://www.libr.org/ISC/.

Oberg, Larry R. (2000). Robert Kent and Friends of Cuban Libraries. Library Juice 3:34. Accessed January 17, 2004 at: http://www.libr.org/Juice.

Oberg, Larry R. (2001). Cuba Today, Tomorrow, Forever." Information for Social Change 13. Accessed January 17, 2004 at: http://www.libr.org/ISC/.

Pateman, John. (1999/2000). "Friends" Versus Supporters of Cuban Libraries. Information for Social Change 10. Accessed January 17, 2004 at: http://www.libr.org/ISC/.

Pateman, John. (2000). Libraries in Cuba: Report of a Visit to "Independent," National and Public libraries in Cuba." Information for Social Change 13. Accessed January 17, 2004 at: http://www.libr.org/ISC/.

Pateman, John. (2002/2003). National Cultural Award of Cuba. Information for Social Change 16. Accessed January 17, 2004 at: http://www.libr.org/ISC/.

Seidelin, Susanne. (2001). Libraries in Cuba: An IFLA/FAIFE Report on Free Access to Information in Cuba." IFLA/FAIFE Report on Cuba / August 2001. Accessed January 17, 2004 at: http://www.ifla.org/faife/faife/cubareport2001.htm.

Sparanese, Ann. (1999). Some Words on the So-Called 'Friends of Cuban Libraries'. Library Juice 2:36. Accessed January 17, 2004 at: http://www.libr.org IJuice/. 